\title{
Удосконалення діагностики післяопераційних атрофічних та нормотрофічних рубців шкіри шляхом застосування колірної системи RGB
}

\author{
Д. С. Аветіков, О. П. Буханченко, С. О. Ставицький, О. С. Іваницыка, В. М. Скрипник \\ Українська медична стоматологічна академія, м. Полтава
}

\section{Improvement of diagnosis of postoperative atrophic and normotrophic cicatrices of skin, using application of the RGB colors system}

\author{
D. S. Avetikov, O. P. Bukhanchenko, S. O. Stavitsky, O. S. Ivanytska, V. M. Scrypnyk \\ Ukrainian Medical Stomatological Academy, Poltava
}

\section{Реферат}

Мета. Удосконалення методів диференціальної діагностики атрофічних та нормотрофічних рубців шкіри голови та шиї шляхом використання комп’ютерної візуалізації цифрових світлин із застосуванням колірної системи RGB (Red, Green, Blue).

Матеріали і методи. Ми спостерігали 60 пацієнтів із післяопераційними рубцями шкіри голови та шиї. Рубцевозмінену тканину додатково обстежували, аналізуючи цифрові світлини у програмі Adobe Photoshop СС iз використанням системи кольорів RGB.

Результати. Застосовуючи колірну систему RGB у діагностиці післяопераційних рубців шкіри щелепно-лицевої ділянки, достовірно визначали тип рубця. Залежно від типу рубця обирали оптимальний метод хірургічного втручання або консервативної терапії.

Висновки. Застосування системи кольорів RGB у програмі Adobe Photoshop CC дає можливість диференціювати атрофічні та нормотрофічні рубці шкіри за показниками інтенсивності забарвлення кольоровим спектром.

Ключові слова: нормотрофічний рубець; атрофічний рубець; система RGB; діагностика.

\section{Abstract}

Objective. Improvement of the differential diagnosis methods for atrophic and normotrophic cutaneous cicatrices of head and neck, using computeric visualization of digital parameters with the RGB (Red, Green, Blue) colors system.

Materials and methods. There were observed 60 patients, suffering postoperative cutaneous cicatrices of head and neck. Cicatricially changed tissue was additionally examined, analyzing digital parameters in the Adobe Photoshop CC program, using the RGB colors system.

Results. A cicatrices type was revealed trustworthily, using the RGB color system while diagnosis of postoperative cutaneous cicatrices in maxillofacial region. Depending on a cicatrices type, the optimal method of surgical intervention or conservative therapy was selected.

Conclusion. Application of the RGB colors system in the Adobe Photoshop CC program permits to differentiate atrophic and normotrophic cutaneous cicatrices in accordance to indices of the colorization intensity by a color spectrum.

Keywords: normotrophic cicatrix; atrophic cicatrix; RGB system; diagnosis.

Післяопераційні патологічні рубці шкіри мають значну частоту виникнення, лікування їх недостатньо ефективне, можливі рецидиви [1].

Для діагностики типу рубця застосовують цілий комплекс додаткових досліджень. 3 огляду на це неабиякий інтерес викликають повідомлення про результати вивчення дії на рубці шкіри ультрафіолетових променів, застосування методів капіляроскопії, рентгенологічних та гістологічних досліджень [2 - 4].

Натепер не існує певної систематизації методів діагностики, всі вони мають свої переваги і недоліки, а повноцінне лікування пацієнтів з рубцевими змінами шкіри можливе лише за умови оптимізації методів диференціальної діагностики різних типів рубців [5 - 7].

Мета дослідження: вдосконалення методів диференціальної діагностики атрофічних та нормотрофічних рубців шкіри голови та шиї шляхом використання комп'ю- терної візуалізації цифрових світлин із застосуванням колірної системи RGB.

\section{Матеріали і методи дослідження}

Обстежено 60 пацієнтів із нормотрофічними й атрофічними рубцями голови та шиї. Терміни розвитку рубцевої тканини становили від 3 до 12 міс. Ми спостерігали пацієнтів, у яких тип рубця був заздалегідь підтверджений не лише клінічно, а й морфологічно.

За норму брали дані кольорового спектру симетричної інтактної ділянки шкіри.

Застосовуючи колірну систему RGB, використовували 8-бітні цифрові зображення із піксельною складовою 24 біти (по 8 бітів на кожен колір). Максимальне значення чистого червоного кольору визначали як R/255 - G /0$\mathrm{B} / 0$. Аналогічно визначали максимальні значення чистих зеленого та синього кольорів. 


\section{Результати}

Досліджено розподіл кольорових констант червоного, зеленого та синього кольорів у чотирьох ділянках: інтактна шкіра (Т1), медіальний (Т2), дистальний (Т3) краї і середина (T4) рубця. Обстеження проводили, враховуючи різні рівні світіння: ідеальне, задовільне, недостатнє.

Систематизувавши отримані дані, ми створили стандартизовані таблиці цифрових значень розподілу кольорових компонентів у системі RGB (див. таблищю).

У ділянці інтактної шкіри (Т1) показники інтенсивності всіх спектральних кольорів мали тенденцію до зниження. Найбільш широкий інтервал показників фіксували за задовільного світіння. За недостатнього світіння показники інтенсивності червоного кольору знижувалися в середньому на 6 одиниць, зеленого - на 4 одиниці, синього - на 10 одиниць. Таким чином, у характеристиці спектральних кольорів інтактної шкіри в залежності від рівня світіння найбільшу роль відіграє синій колір.

Під час комп'ютерної візуалізації цифрових світлин нормотрофічних рубців у ділянці Т2 за недостатнього світіння реєстрували зменшення показників інтенсивності червоного кольору в середньому на 6 одиниць порівняно 3 показниками за ідеального світіння, що свідчило про широкий спектральний діапазон цього кольору за різних рівнів світіння.

Показники інтенсивності зеленого кольору залишалися майже незмінними. Якщо припустити, що незмінність показників інтенсивності зеленого компонента спектру властива лише нормотрофічним рубцям, це надає лікареві змогу під час первинної спектральної діагностики типу рубця встановити правильний попередній діагноз.

Показники інтенсивності синього кольору за ідеального і задовільного світіння мало відрізнялися, в середньому на 3 одиниці. Таким чином, порівняльний аналіз показників інтенсивності трьох кольорів у системі RGB під час спектральної візуалізації тканин у медіальному краї рубця показав, що максимальні відмінності мали показники червоного кольору, мінімальні - синього, а зеленого майже не змінювалися.

Аналіз результатів дослідження із застосуванням колірної системи RGB рубцевих тканин у ділянці Т3 засвідчив, що показники інтенсивності всіх трьох кольорів дещо перевищували відповідні показники в ділянці Т2. У разі зниження світіння до недостатнього також спостерігали зменшення показника інтенсивності червоного кольору на 6 одиниць, як і в ділянці Т2. Показники інтенсивності зеленого кольору знижувалися в середньому на 4 одиниці, що відрізнялося від динаміки змін показників інтенсивності зеленого кольору в ділянці Т2.

Найбільші зміни показників інтенсивності відбувалися в спектрі синього кольору - в середньому ці показники стали менші на 9 одиниць.

У ділянці Т4 динаміка змін показників інтенсивності червоного і синього кольорів у залежності від рівня світіння була майже однаковою. У разі зниження рівня світіння до недостатнього показники інтенсивності червоного кольору зменшувалися на 7 одиниць, синього - на 8 одиниць. Показники інтенсивності зеленого кольору характеризувались однаковим зменшенням незалежно від рівня світіння: на 4 одиниці за задовільного і недостатнього світіння порівняно з ідеальним.

Під час спектральної візуалізації тканин атрофічних рубців у ділянці Т2 спостерігали показники інтенсивності червоного компонента спектру, які були менші в середньому на 9 одиниць у залежності від різних рівнів світіння. Показники інтенсивності зеленого компонента спектру також зменшувалися в середньому на 9 одиниць. Найбільші зміни були характерними для інтервалу показників інтенсивності синього кольору - 11 одиниць, що, на наш погляд, є важливим прогностичним критерієм у діагностиці атрофічних рубців у їх медіальному краї.

У ділянці Т3 інтенсивність показників червоного кольору за недостатнього світіння зменшувалась у середньому на 11 одиниць, а інтенсивність показників зеленого кольору - на 9 одиниць порівняно з відповідними показниками за ідеального світіння.

Найбільш широкий діапазон змін також спостерігали щодо синього спектру - показники інтенсивності були менші в середньому на 14 одиниць. Отже, динаміка спектральних показників у ділянці дистального краю рубця і в ділянці його медіального краю була однаковою.

У ділянці Т4 показники інтенсивності червоного кольору зменшувались в середньому на 11, зеленого - на 9 одиниць. Найбільше зменшення спостерігали щодо показників інтенсивності синього кольору - в середньому на 13 одиниць.

Забарвлення трьома кольорами в системі RGB у медіальному та дистальному краях рубця і його середині ма-

\begin{tabular}{|c|c|c|c|c|c|c|c|c|}
\hline \multicolumn{9}{|c|}{$\begin{array}{l}\text { Розподіл інтервалів цифрових значень кольорових компонентів у системі RGB під час візуалізації різних типів } \\
\text { післяопераційних рубців та інтактної шкіри }\end{array}$} \\
\hline \multirow{3}{*}{$\begin{array}{l}\text { Рівень } \\
\text { світіння }\end{array}$} & \multirow{3}{*}{$\begin{array}{l}\text { Кольоровий } \\
\text { спектр }\end{array}$} & \multirow{3}{*}{$\begin{array}{c}\text { Інтактна } \\
\text { шкіра }\end{array}$} & \multicolumn{6}{|c|}{ Післяопераційні рубці } \\
\hline & & & \multicolumn{3}{|c|}{ нормотрофічні } & \multicolumn{3}{|c|}{ атрофічні } \\
\hline & & & $\mathrm{T} 2$ & T3 & T4 & T2 & T3 & T4 \\
\hline \multirow{3}{*}{ Ідеальне } & Червоний & $82 \pm 3$ & $79 \pm 2$ & $85 \pm 2$ & $87 \pm 2$ & $90 \pm 2$ & $91 \pm 2$ & $92 \pm 2$ \\
\hline & Зелений & $28 \pm 2$ & $25 \pm 2$ & $30 \pm 3$ & $32 \pm 3$ & $35 \pm 3$ & $36 \pm 3$ & $37 \pm 3$ \\
\hline & Синій & $11 \pm 2$ & $13 \pm 2$ & $12 \pm 3$ & $13 \pm 2$ & $18 \pm 3$ & $19 \pm 3$ & $20 \pm 3$ \\
\hline \multirow{3}{*}{ Задовільне } & Червоний & $79 \pm 4$ & $78 \pm 2$ & $80 \pm 2$ & $81 \pm 2$ & $85 \pm 2$ & $86 \pm 2$ & $87 \pm 2$ \\
\hline & Зелений & $26 \pm 3$ & $25 \pm 3$ & $26 \pm 3$ & $28 \pm 3$ & $29 \pm 3$ & $30 \pm 3$ & $32 \pm 3$ \\
\hline & Синій & $08 \pm 6$ & $10 \pm 5$ & $11 \pm 5$ & $13 \pm 5$ & $14 \pm 5$ & $12 \pm 5$ & $15 \pm 5$ \\
\hline \multirow{3}{*}{ Недостатнє } & Червоний & $76 \pm 5$ & $73 \pm 5$ & $79 \pm 5$ & $80 \pm 5$ & $81 \pm 5$ & $80 \pm 5$ & $81 \pm 5$ \\
\hline & Зелений & $24 \pm 4$ & $23 \pm 4$ & $26 \pm 5$ & $28 \pm 5$ & $26 \pm 5$ & $27 \pm 5$ & $28 \pm 5$ \\
\hline & Синій & $01 \pm 3$ & $02 \pm 3$ & $03 \pm 2$ & $05 \pm 3$ & $07 \pm 3$ & $05 \pm 3$ & $07 \pm 3$ \\
\hline
\end{tabular}


ло різну інтенсивність, саме тому економічно доцільно під час консервативного лікування передбачати різний концентраційний градієнт розчину препарату, який вводиться в товщу рубця.

\section{Обговорення}

Застосування колірної системи RGB у діагностиці рубців шкіри є достатньо інформативним методом обстеження, за його допомогою можливо об'єктивно й безпечно як оцінювати структуру рубцевозміненої тканини, так і визначати тип та товщину рубця. Даний метод дає змогу встановити відмінності у цифрових складових кольорів спектру, різницю у їх формі та об'ємних частках, фігурах спектру кольорового забарвлення, а також визначити внутрішньо-групові відмінності в інтервалах діапазону, зміну цифрових показників кольорового забарвлення в різних ділянках атрофічних та нормотрофічних рубців шкіри голови та шиї.

\section{Висновки}

1. Проведеним кількісним та якісним цифровим колірним аналізом встановлено, що різні типи рубців мають внутрішньо-групові відмінності в інтервалах діапазону, відрізняються цифровими показниками кольорового забарвлення в різних ділянках, характеризуються різновидом цифрових даних візуалізованих кольорових спектрів.

2. Отримані дані дають підставу вважати доцільним використання цифрової кольорової візуалізації поверхні інтактної шкіри та післяопераційних рубців із застосуванням колірної системи RGB на етапі первинної діагностики для встановлення попереднього діагнозу.

\section{References}

1. Avetikov DS, Trapova KhO. Porivnialna kharakterystyka efektyvnosti metodiv profilaktyky utvorennia patolohichnykh rubtsiv. Aktualni problemy suchasnoi medytsyny: Visnyk Ukrainskoi medychnoi stomatolohichnoi akademii. 2013;(6):18-21. [In Ukrainian].

2. Avetikov DS, Trapova KhO. Perevahy i nedoliky isnuiuchykh metodyk profilaktyky utvorennia patolohichnykh rubtsiv. Aktualni problemy suchasnoi medytsyny: Visnyk Ukrainskoi medychnoi stomatolohichnoi akademii. 2013;(43):10-2. [In Ukrainian].

3. Skrypnyk VM, Kaidashev IP, Shlykova OA, Avetikov DS. Polimorfizm G28197A $>$ G henu elastanu vyznachaie skhylnist do utvorennia patolohichnykh rubtsiv. Problemy ekolohii i medytsyny. 2012;(5-6):614. [In Ukrainian].

4. Loza KhO, Stavytskyi SO, Loza YeO, Voloshyna LI, Avetikov DS Klinichna kharakterystyka stanu rubtsevo-zminenykh tkanyn shkiry pislia operatsii. Klinichna khirurhiia. 2016;885:61-3. [In Ukrainian].

5. Feng CH, Yang JV, Chang CY. Free medial thin prtrolaor flap for reconstruction of the dynamic and static complex burn scar contracture. Burns; 2009;(10):567-73.

6. Timofeev AA. Rubcy: osobennosti klinicheskogo techenija i lechenija Sovremennaja stomatologija. 2008;(3):70-83. [In Russian].

7. Guller AE, Shehter AB. Klinicheskij tip i gistologicheskaja struktura kozhnyh rubcov kak prognosticheskie faktory ishoda lechenija. Annaly plasticheskoj, rekonstruktivnoj i jesteticheskoj hirurgii. 2007;(4):1924. [In Russian]. 